https://doi.org/10.31426/ijamsr.2018.1.10.1014

\title{
Factors that Affect Potential Investors in case of Choosing the Optimal Investment from the Stream of Investment Alternatives: A Case Study on Bangladeshi Investors
}

\author{
Md Saddam Hossain Khan ${ }^{1}$, Afsana Tajnin ${ }^{2}$ \\ ${ }^{1,2}$ Lecturers, Business Administration Department, Bangladesh University, Dhaka, Bangladesh
}

Email: saddam.bba.ju@gmail.com

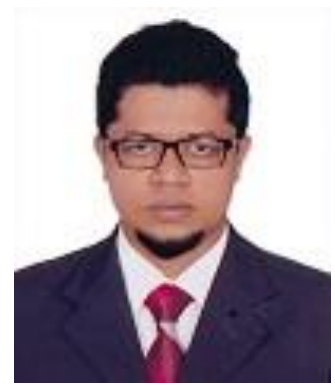

MD SADDAM HOSSAIN KHAN

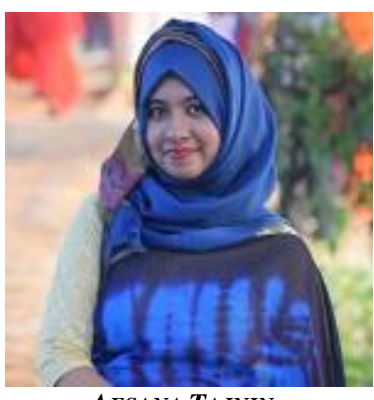

AFSANA TAJNIN

\begin{abstract}
A B S T RA C T
This is a primary data based survey to identify the potential factors that play the most crucial role in choosing the optimal investment for the potential investors. We have mainly taken into account 16 broad factors which have been collected from different brokerage houses of Dhaka, Bangladesh. This broad factor encompasses Regulations, Internal, External, and Market Image of Bangladesh capital market. The findings of this study could be beneficial for the potential investors invest their capital effectively.
\end{abstract}

Citation: Md Saddam Hossain Khan, Afsana Tajnin (2018). Factors that Affect Potential Investors in case of Choosing the Optimal Investment from the Stream of Investment Alternatives: A Case Study on Bangladeshi Investors. International Journal of Advanced Multidisciplinary Scientific Research (IJAMSR ) ISSN:2581-4281 Vol 1, Issue 10, December, 2018, \#Art.1014, pp 27-33
Introduction

"What factor should we consider to identify the best investment among the stream of investments?" has been considered as a burning question since the inception of the stock market. Potential investors face a tremendous amount of difficulty to find the optimal investment that will increase the value of the total wealth of that specific 


\section{International Journal of Advanced Multidisciplinary Scientific Research (IJAMSR) ISSN:2581-4281}

personal or business. So it is an urgent necessity to know which factors we should emphasize on among available factors before investing our valuable money. Throughout this primary data-based study, we have tried to identify the intensity of the most influencing factors that should be considered in order to invest our money in the optimal projects. Factors encompassing broader categories are Regulatory and Internal, External and Market Image, Change in Government and policy been considered as they are found to be influential.

\section{Literature Review}

Generally, the main objective of the investment is to maximize the wealth of the individual or firm. The more we wish to gain profit the more we need to bear the risk related to the investment (Azam \& Kumar, 2011). So to maximize the wealth of an individual or organization, selection of the best profit potential project is a must.

There exists a huge amount of factors available that may strongly or less strongly affect the potential investor at the time making an investment decision. The fundamental rule of Investment is to secure the most extreme return with least Risk (Babajide \& Adetiloye 2012). The normal rate of return from an Investment option ought to be precise. Since it is an estimate, there is typically some changeability about the exact measure of the return (Chandra \& Kumar 2008). On the off chance that the normal rate of return is not precise then the financial specialist may redirect or change his interest in different choices.

Risk is the changeability of conceivable Returns around the expected return of an Investment (Benson, D. J. 2002). Every Financial specialist has his/her own state of mind about risk and the amount he or she can endure.
Since Speculations of risk related to them, the Speculator must figure out which, mix options coordinate his or her specific risk resistances (Docking \& Koch, 2005).

The government tax approach is likewise a deciding variable while picking among investment choices (Geetha \& Ramesh, 2012). It also depends upon the perception of different investors that some may be interested in tax-exempt asset while others may be interested in high yielding but taxable returning assets. The investors should also consider about tax laws that provide many deductions in the consumption of taxable income.

Investment period is also a factor to determine the investment alternatives. The return on investment is affected by the investment period. It affects not only the return and risk but also frequently the tax consequences associated with the return (Jain \& Mandot (2012).

Another important element while choosing an investment alternative is timing. It refers to purchasing an asset just before it is likely to increase in value and selling the asset just before it is likely to decrease in value (Joseph, \& Vezos, 2006).

These are largely dependent on the structure and processes of a Capital Market system and the country, which it is associated with. Due to economic fluctuations such as the recession and the recent global economic crisis, the structure of the global Capital Markets has been strengthened by increasing the authority of regulatory authorities (Shaikh, \& Kalkundrikar 2011) setting up new authorities and on having Central Counter Parties (CCP) responsible for the execution of Trade (Guaran Levine\& Zervos, 1998). 
https://doi.org/10.31426/ijamsr.2018.1.10.1014

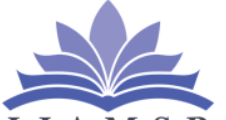

I J A M S R

International Journal of

Advanced Multidisciplinary Scientific Research (IJAMSR) ISSN:2581-4281

Reliable systems need to be available and operational all the time irrespective of risks from internal failures and external events (Maysami \& Koh, 2000).

\section{Methodology:}

Mainly we are conducting a primary data based descriptive research. To measure the influential factors and their intensity for investment, firstly we have identified 16 broad category factors which represent more than 40 specific factors from different brokerage houses of Bangladesh. Then we have issued a structured questionnaire where respondents were asked to respond against 16 close-ended variables on 5 points Likert Scale where 5 stands for strongly Important and 1 stands for strongly Unimportant. After that, we have determined some factors among all the factors we have collected by using factor analysis of SPSS.

Among the total sample of 220, 110 has collected by using judgmental sampling (Investors having basic educational knowledge of investment) and the rest of them has collected by using simple random sampling (Investors dependent on third-party decision).

\section{Measuring the Intensity of the Factors:}

\section{Kaiser Meyer Olkin (KMO) and Bartlett's Test:}

The KMO measures the sampling adequacy (which determines if the responses given by the sample are adequate or not) which should be closer to 0.5 for a satisfactory factor analysis to proceed.

Table 1: Kaiser Meyer Olkin (KMO) and Bartlett's Test

\begin{tabular}{|l|l|}
\hline \multicolumn{2}{||l|}{ KMO and Bartlett's Test } \\
\hline Kaiser-Meyer-Olkin & .57 \\
Measure of Sampling & $\mathbf{0}$ \\
Adequacy. & \\
\hline
\end{tabular}

\section{Source: SPSS Calculation}

Looking at the table above, the KMO measure is.570 which is more than 0.5 . So the model we are running is acceptable and we can conclude that the responses given by the sample are adequate enough to be a perfect model of factor analysis.

The bartlett's test is another indication of the strength of the relationship among variables. This tests the null hypothesis that the correlation matrix is an identity matrix. An identity matrix is matrixes in which all of the diagonal elements are 1 and all off-diagonal elements (above and below the diagonal) are close to 0 .

\begin{tabular}{|l|l|l|}
\hline \multirow{3}{*}{$\begin{array}{l}\text { Bartlett's } \\
\text { Test } \begin{array}{l}\text { Sest } \\
\text { Sphericity }\end{array}\end{array}$} & $\begin{array}{l}\text { Approx. } \\
\text { of }\end{array}$ & 372.504 \\
\cline { 2 - 3 } & Chi-Square & \\
\cline { 2 - 3 } & Sig. & $\mathbf{1 2 0}$ \\
\hline
\end{tabular}

We want to reject this null hypothesis. From the same table, we can see that Bartlett's Test of Sphericity is significant (0.00). That is, the significance is less than 0.05. In fact, it is actually 0.000 , i.e. the significance level is small enough to reject the null hypothesis. This means that correlation matrix is not an identity matrix. So we can infer that our model is effective for further analysis. 
https://doi.org/10.31426/ijamsr.2018.1.10.1014

I J A M S R

\section{International Journal of} Advanced Multidisciplinary Scientific Research (IJAMSR) ISSN:2581-4281

\section{Commonalities:}

Commonalities show how much of the variance (i.e. the commonality value which should be more than 0.5 to be considered for further analysis) in the variables have been accounted for by the extracted factors.

Table 2: commonalities

\begin{tabular}{|l|l|}
\hline & Extraction \\
\hline Rate of Return & .573 \\
Risk & .648 \\
Taxes & .819 \\
Investment Period & .695 \\
Investment Timing & .521 \\
Available Money to Invest & .729 \\
Systematic Risk & .598 \\
Efficiency of the System & .675 \\
Reliability of the System & .582 \\
Technological Influence & .517 \\
Past Market Trends & .492 \\
Risk Appetite & .723 \\
Investible Surplus & .769 \\
Money Demand at Maturity & .617 \\
Political Stability & .658 \\
Diversification & .638 \\
\hline
\end{tabular}

For instance, over $80 \%$ of the variance in "Quality of Taxes" is accounted for, while $72.9 \%$ of the variance in "Available Money to Invest" is accounted for.

Total variance explained:

Table 3: Total Variance Explained

\begin{tabular}{|c|c|c|c|c|c|c|c|c|c|}
\hline \multirow[t]{2}{*}{ Component } & \multicolumn{3}{|c|}{ Initial Eigenvalues } & \multicolumn{3}{|c|}{$\begin{array}{l}\text { Extraction Sums of Squared } \\
\text { Loadings }\end{array}$} & \multicolumn{3}{|c|}{$\begin{array}{l}\text { Rotation Sums of Squared } \\
\text { Loadings }\end{array}$} \\
\hline & Total & $\mid \begin{array}{ll}\% \\
\text { Variance }\end{array}$ & of Cumulative \% & Total & $\mid \begin{array}{lr}\% & \text { of } \\
\text { Variance }\end{array}$ & Cumulative \% & Total & $\begin{array}{l}\% \\
\text { Variance }\end{array}$ & $\begin{array}{l}\text { Cumulative } \\
\% \\
\end{array}$ \\
\hline 1 & 2.191 & 13.692 & 13.692 & 2.191 & 13.692 & 13.692 & 1.955 & 12.218 & 12.218 \\
\hline 2 & 1.737 & 10.855 & 24.547 & 1.737 & 10.855 & 24.547 & 1.477 & 9.230 & 21.447 \\
\hline 3 & 1.455 & 9.095 & 33.642 & 1.455 & 9.095 & 33.642 & 1.424 & 8.901 & 30.348 \\
\hline 4 & 1.379 & 8.616 & 42.258 & 1.379 & 8.616 & 42.258 & 1.413 & 8.833 & 39.181 \\
\hline 5 & 1.283 & 8.021 & 50.279 & 1.283 & 8.021 & 50.279 & 1.395 & 8.721 & 47.902 \\
\hline 6 & 1.146 & 7.166 & 57.444 & 1.146 & 7.166 & 57.444 & 1.384 & 8.647 & 56.549 \\
\hline 7 & 1.064 & 6.650 & 64.094 & 1.064 & 6.650 & 64.094 & 1.207 & 7.545 & 64.094 \\
\hline 8 & .880 & 5.500 & 69.595 & & & & & & \\
\hline 9 & .803 & 5.019 & 74.614 & & & & & & \\
\hline 10 & .705 & 4.405 & 79.019 & & & & & & \\
\hline 11 & .681 & 4.255 & 83.274 & & & & & & \\
\hline 12 & .605 & 3.783 & 87.057 & & & & & & \\
\hline 13 & .576 & 3.600 & 90.657 & & & & & & \\
\hline 14 & .542 & 3.386 & 94.043 & & & & & & \\
\hline 15 & .487 & 3.046 & 97.090 & & & & & & \\
\hline 16 & .466 & 2.91 & 11000 & & & & & & \\
\hline
\end{tabular}

"Eigenvalue" actually reflects the number of extracted factors whose sum should be equal to a number of items which are subject to factor analysis. For analysis and interpretation purpose, we are only concerned with Extracted Sums of Squared Loadings. Here one should note that the first factor accounts for $13.692 \%$ of the variance, the second $10.895 \%$, the third $9.095 \%$, the forth $8.616 \%$, the fifth $8.021 \%$, the sixth $7.166 \%$, and the eighth is $6.650 \%$. The minimum cumulative variance explained by the factors having "Eigen value" more than 1 must have to be greater than $60 \%$. At our table, we have got $64.094 \%$, which is greater than our minimum level. So we can conclude that our model is totally fit for further analysis.

\section{Scree Plot:}

The Scree plot is a graph of the eigenvalues against all the factors. The graph is useful for determining how many factors to retain. The point of interest is where the curve starts to flatten. 
https://doi.org/10.31426/ijamsr.2018.1.10.1014

Figure 01: Scree Plot

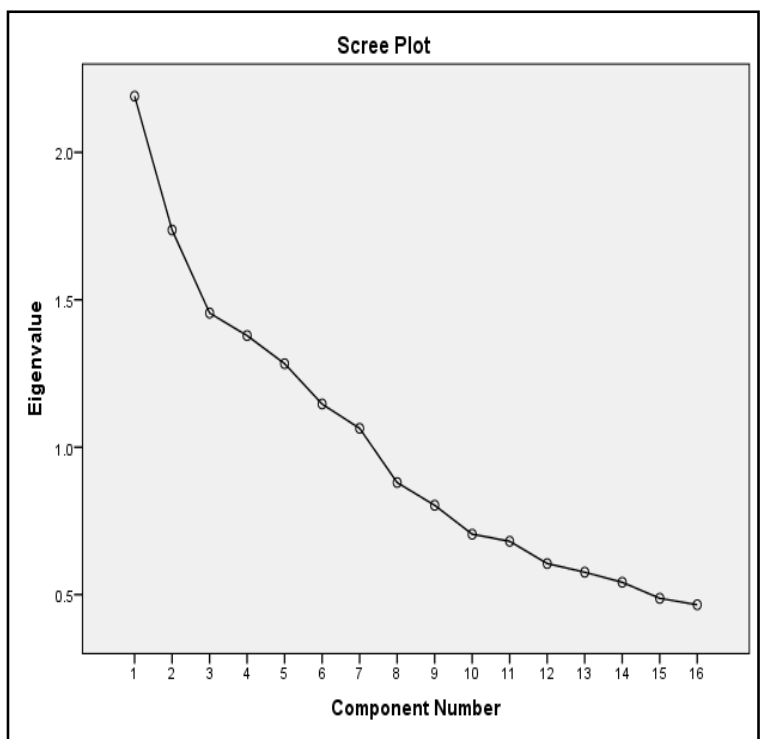

\section{Source: SPSS Calculation}

It can be seen that the curve begins to flatten between factors 7 and 8 . Note also that factor 8 onwards have an eigenvalue of less than 1 , so only seven factors have been retained.

\section{Component Matrix:}

The table below shows the loadings (extracted values of each item under 7 variables) of the sixteenth variables on the seven factors extracted. The higher the absolute value of the loading, the more the factor contributes to the variable (We have extracted seven variables wherein the 16 items are divided into 7 variables according to most important items which similar responses in component 1,2,3,4,5,6 and 7). The gap (empty spaces) on the table represents loadings that are less than 0.5, this makes reading the table easier. We suppressed all loadings less than 0.4 .
Table 4: Component Matrix

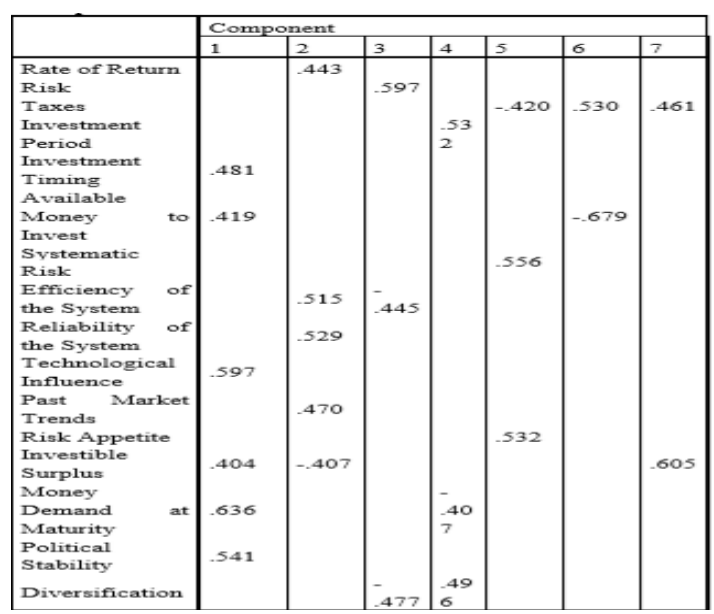

\section{Rotated Component Matrix:}

The idea of rotation is to reduce the number factors on which the variables under investigation have high loadings. Rotation does not actually change anything but makes the interpretation of the analysis easier.

Table 5: Rotated Component Matrix

\begin{tabular}{|c|c|c|c|c|c|c|c|}
\hline & \multicolumn{7}{|c|}{ Component } \\
\hline & 1 & 2 & 3 & 4 & 5 & 6 & 7 \\
\hline \begin{tabular}{|l|} 
Rate of Retum \\
Risk \\
Taxes \\
Investment Period \\
Investment Timing \\
Available Money to \\
Invest \\
Systematic Risk \\
Efficiency of the System \\
Reliability of the System \\
Technological Influence \\
Past Market Trends \\
Risk Appetite \\
Investible Surplus \\
Money Demand at \\
Maturnity \\
Political Stability \\
Diversification
\end{tabular} & $\begin{array}{l}.547 \\
519\end{array}$ & .576 & .493 & .622 & .706 & .760 & .884 \\
\hline
\end{tabular}

Source: SPSS Calculation 


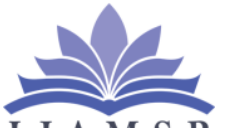

International Journal of Advanced Multidisciplinary Scientific Research (IJAMSR) ISSN:2581-4281

From the table, we can see that Investment Timing, Available Money to Invest, Technological Influence and Money Demand at Maturity are substantially loaded on factor 1 and now we can name factor as Available Money \& Investment. Risk, Past Market Trends, and Political Stability are substantially loaded on factor 2 and the name is Market trend $\boldsymbol{\&}$ Risk. Reliability of the System and Diversification are significantly loaded on factor 3 and the name will be System \& Diversification. The rate of Return and Efficiency of the System is strongly loaded on factor 4 and we name it as Rate of Return. Systematic risk and Risk appetite are loaded on factor 5 and we call it Intensity of Risk Taking. Investment Period and Investible Surplus are loaded on factor 6 and we name it Investment period and Surplus and the last is taxes, which loaded on factor 7 and our name the factor as Tax.

\section{Conclusion:}

After all the analysis finally, we have got 7 factors out of 16 factors which play an influential role at the time of deciding an investment by a potential investor. These factors must need to remember at the time of choosing an investment.

\section{References}

1) Ben Zion, U., Choi, J. J., \&Hasuer, S. (1996). The price linkages between country funds and national stock markets: evidence of cointegration and causality tests of German, Japan, and UK funds. Journal of Business Finance and Accounting, 23, 1005-17

2) Maysami, R. C.\& Koh, T. S. (2000). A vector error correction model of the Singapore stock market. International Review of Economics \& Finance, 9(1).

3) Joseph, N. L., \& Vezos, P. (2006). The sensitivity of US banks' stock returns to interest rate and exchange rate changes. Managerial Finance, 32(2), 182-199.

4) Benson, D. J. (2002). The effects of stock market development on growth and private investment in lower-income countries. Emerging Markets Review, $3(3), 211-232$
5) Azam, M \& Kumar, D. (2011). Factors Influencing the Individual Investor and Stock Price Variation: Evidence from Karachi Stock Exchange. Australian Journal of Basic and Applied Sciences, 5(12): 30403043, 2011

6) Geetha, N., \& Ramesh, M. (2012), A Study on Relevance of Demographic Factors in Investment Decisions. International Journal of Financial Management (IJFM), 1(1), 39-56.

7) Dhaka Stock Exchange.(2008). DSE Monthly Reviews \& Graphs. Dhaka Stock Exchange. Retrieved August 27, 2010, from http://www.dsebd.org/gr_oct08.php

8) Dhaka Stock Exchange. (2010b, August).Market Statistics. Dhaka Stock Exchange. Retrieved August 25, 2010, from http://web.dsebd.org/admin$\mathrm{real} / \mathrm{mst} . \mathrm{txt}$

9) Ahmed, A. (2008, February 24). Foreign investment in Bangladesh market surges. Reuters. Dhaka. Retrieved from http://in.reuters.com/article/idINDHA199945200802 24

10) Chandra, A., \& Kumar, R. (2008). Decision Making in the Stock Market: Incorporating Psychology with Finance. In the Proceedings of the Conference on Forecasting Financial Markets in India at IIT Kharagpur, India. December 2008 
https://doi.org/10.31426/ijamsr.2018.1.10.1014

I J A M S R

International Journal of

Advanced Multidisciplinary Scientific Research (IJAMSR) ISSN:2581-4281

Questionnaire

Little Description:

Dear Respondent:

It is to inform you that I am conducting a research on

"Factors that affect potential investors in case of choosing the optimal investment from stream of Investment alternatives: A Case study on

Bangladeshi Investors". To complete this research I need your kind cooperation.

\begin{tabular}{|l|l|l|l|l|l|}
\hline & 1 & 2 & 3 & 4 & 5 \\
\hline Rate of Return & & & & & \\
\hline Risk & & & & & \\
\hline Taxes & & & & & \\
\hline $\begin{array}{l}\text { Investment } \\
\text { Period }\end{array}$ & & & & & \\
\hline $\begin{array}{l}\text { Investment } \\
\text { Timing }\end{array}$ & & & & & \\
\hline $\begin{array}{l}\text { Available } \\
\text { Money to Invest }\end{array}$ & & & & & \\
\hline Systematic Risk & & & & & \\
\hline $\begin{array}{l}\text { Efficiency of the } \\
\text { System }\end{array}$ & & & & & \\
\hline $\begin{array}{l}\text { Reliability of } \\
\text { the System }\end{array}$ & & & & & \\
\hline $\begin{array}{l}\text { Technological } \\
\text { Influence }\end{array}$ & & & & & \\
\hline $\begin{array}{l}\text { Past Market } \\
\text { Trends }\end{array}$ & & & & & \\
\hline Risk Appetite & & & & & \\
\hline $\begin{array}{l}\text { Investible } \\
\text { Surplus }\end{array}$ & & & & & \\
\hline $\begin{array}{l}\text { Money Demand } \\
\text { at Maturity }\end{array}$ & & & & & \\
\hline $\begin{array}{l}\text { Political } \\
\text { Stability }\end{array}$ & & & & & \\
\hline Diversification & & & & & \\
\hline
\end{tabular}

